\title{
Studies on the efficacy of black soap and kerosene mixture on the control of Pod sucking bugs (Clavigralla tomentosicollis stal.) on Cowpea (Vigna unguiculata (L.) Walp)
}

\author{
Aliyu, M. ${ }^{1}$, T. Ladan ${ }^{1}$, B.I. Ahmed ${ }^{1}$ and J. Abdullahi ${ }^{2}$ \\ ${ }^{1}$ Crop Production Program, School of Agriculture, Abubakar Tafawa Balewa University, \\ Bauchi. ${ }^{2}$ Division of Agricultural Colleges, Samaru College Agriculture, Ahmadu Bello \\ University, Zaria
}

\begin{abstract}
Field experiment testing of various concentrations (2, 4, 6 and 8\% $\mathrm{vol} / \mathrm{vol}$ ) of an aqueous black soap and kerosene as a control for pod damage by Clavigralla tomentosicollis Stal. indicated that the $8 \%$ concentration was the most effective in reducing pod injury and increasing the yield of seed in 'DanSokoto' cowpeas. None of the treatments significantly reduced the abundance of the pod sucking insects on the plants. Application of $8 \%$ concentration should therefore be considered for recommendation as a control to cowpea growers.
\end{abstract}

Key words: Clavigralla tomentosicollis, population, yield, black soap and kerosene.

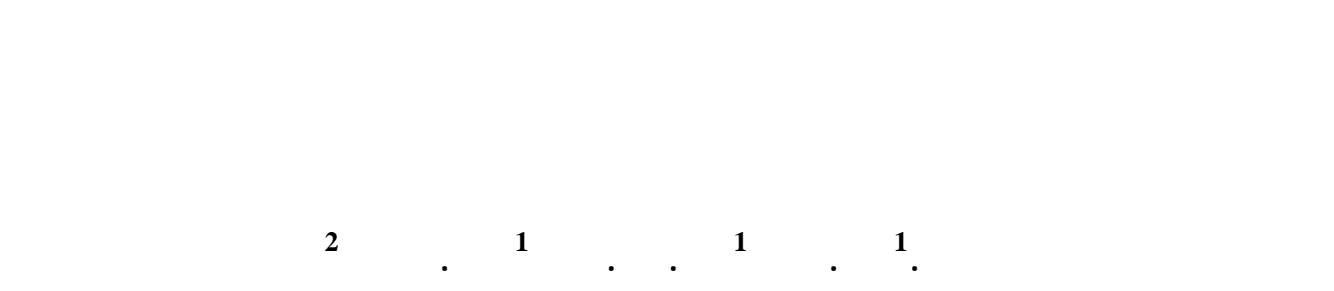

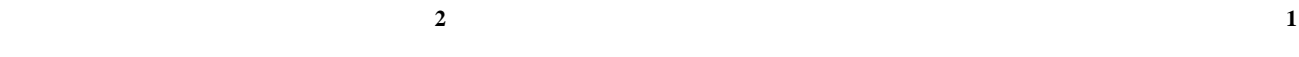
زائير

الملخص: لجريت تجربة حقلية لدرلسة تأثير ترلكيز مختلفة من مزيج الصابون اللسود والكيروسن (2، 4، 6، 8)

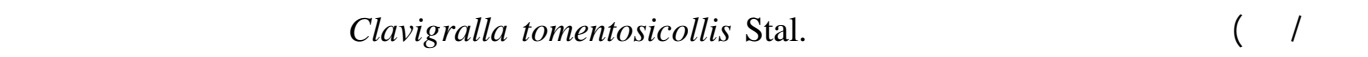

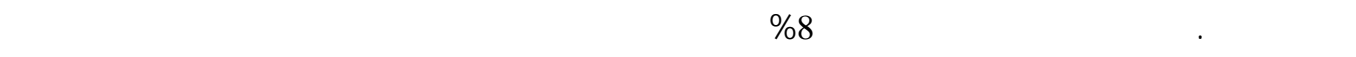

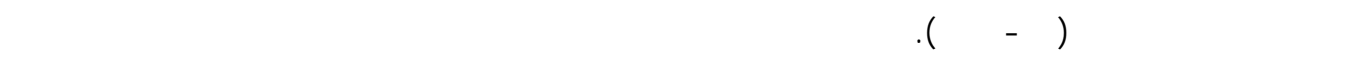

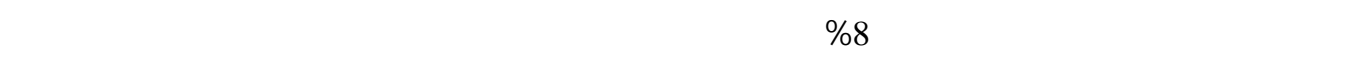
اللوبيا. الكالمال الفتلحية: Clavigralla tomentosicollis ، كثافة، النتاج، الصابون المسود والكيروسين.

\section{Introduction}

The cowpea (Vigna unguiculata (L.) Walp) belongs to the family leguminosae. It is a grain legume that is grown in the savannah regions of the tropics and subtropics. It is also an important pod and fodder crop in different parts of the tropics Quin, (1997). The cowpea is an important food crop which provides high quality protein. Cowpea grains contain $25 \%$ protein, making it extremely 
valuable where many people cannot afford protein foods such as meat and fish. It is also a good source of carbohydrate $(56.86 \%)$ calcium, iron, vitamin B and carotene (Oyenuga, 1987). In many places, it provides more than half of the plant protein in the human diet where it supplements a starch staple (Singh and Rachie, 1985). Although cultivated primarily for its edible seeds, direct consumption of cowpea leaves is also widespread in different parts of Africa (Nelsen et al., 1997). Low yields are a significant attribute of production estimates, $240-300 \mathrm{~kg} / \mathrm{ha}$ is typical in Africa (Singh and Rachie, 1985). This has been attributed largely to damage by pest. Jackai and Adalla (1997) listed at least 20 major insect pest species in the various cowpea growing regions of the world, the number varying from region to region. Some of the most damaging of all the insect pests include the legume flower thrips Megalurothrips sjostedti (Trybom), the legume pod borer Maruca vitrata F., a complex of pod and seed suckers of which Clarigralla tomentosicollis Stal is the dominant species, and the cowpea weevil Callosobruchus maculatus Fab which has been the major storage pest.

C. tomentosicollis sucks the sap from the pods, causing them to shrivel and dry prematurely with resultant loss in yield which has been estimated at between 20-100\% in various parts of Africa (Singh and Allen 1980). Chemical insecticides, in practice, are the major control measures of $C$. tomentosicollis on cowpeas (Singh and Jackai, 1985; Singh et al., 1990 and Adalla 1997), but many of these chemical insecticides have been or will be phased out in Europe and other developed countries of the world. This is because excessive or increased use of chemical insecticides can lead to general environmental contamination, elimination of economically beneficial insects and the development of resistance to the chemical by the pests (Royer et al., 1986, Brodsgaard, 1994 and Immaraju et al
1992). Besides, chemical insecticides are toxic to human health, and also are not affordable by majority of the peasant farmers whose population constitute $80 \%$ of the Nigerian farmers. Furthermore, the global concern over the deleterious effect of chemical insecticides especially on humans and the environment, and of course the demand for pesticide-free food, has triggered efforts for finding alternative and suitable pest management strategies and implementation of appropriate tools for dissemination (Dal Bello et al., 2000; Ekesi et al., 2000 and Batta et al., 2003).

Considering the level of damage caused by $C$. tomentosicollis on cowpeas and the global concern over the use of synthetic chemicals, the objective of this study was therefore to determine the effectiveness of black soap and kerosene for the control of this pest and also to determine the appropriate level of concentration required to give the best result in terms of minimizing the damage and yield increase. Black soap is a locally medicated soap prepared mostly in the southern part of Nigeria. It has been used in the control of fungal infection in children and adults. The potentials of black soap and kerosene for insect control have not been tried before.

\section{Materials and Methods}

The experiment was carried out at the research farm of the School of Agriculture, Abubakar Tafawa Balewa University, Bauchi, during the rainy season of 2004. The field for the experiment was prepared by using a tractor which constructed ridges $75 \mathrm{~cm}$ apart. A total area of $29 \mathrm{~m}$ by $19 \mathrm{~m}$ $\left(551 \mathrm{~m}^{2}\right)$ was marked out. 20 plots each measuring $5 \mathrm{~m}$ by $4 \mathrm{~m}\left(20 \mathrm{~m}^{2}\right)$ were also marked out by using pegs, rope and measuring tape. A discard of 1 meter was allowed between plots and blocks respectively. The experiment was laid out in a completely randomized block design 
which consisted of 5 treatments replicated 4 times. The cowpea variety used for the experiment was Dansokoto (a local variety) which is a prostrate type. It was purchased from Yelwa Market, Bauchi. Three seeds were planted per hole at a distance of $25 \mathrm{~cm}$ within each raw and 75 $\mathrm{cm}$ between rows. 5 days after planting, missing stands were re-sown. At 3 weeks after planting, the cowpea stands were thinned to 2 plants per stand.

Hoe weeding was carried out to suppress the weeds. The experimental site was kept weeds free throughout the period of the experiment.

Single Super Phosphate was applied using drilling system at the rate of $2 \mathrm{~g}$ per cowpea stand 2 weeks after emergence. The treatments of black soap/kerosene were as follows: ( $2 \%, 4 \%, 6 \%$, and $8 \%$ ) slurry in water, in addition to control.

1 milk tin (170g) of black soap was first of all dissolved in $150 \mathrm{ml}$ of water. The suspension was allowed to stay for 4 hours to dissolve properly and was thoroughly stirred. The slurry was then dissolved in 1 litre of kerosene to form a thick and concentrated black soap/kerosene mixture. A measuring cylinder was used to measure $100 \mathrm{ml}$, $200 \mathrm{ml}, 300 \mathrm{ml}$ and $400 \mathrm{ml}$ of the mixture, and each of the concentrations was mixed with 5 litres of water at Birky Knapsack sprayer filled to the mark and was sprayed on the cowpea plots after the cowpeas had started podding, at weekly intervals from 9 weeks after planting to 11 weeks after planting.

Insect pests (C. tomentosicollis) were counted by using the techniques of hand picking and direct physical count a day after each spray. The population was recorded from 5 randomly selected stands from each of the plots from 9-11 weeks after planting. However due to shortage of rainfall, the data on the population was not continued beyond 11 weeks after planting. The picking of cowpea dry pods was carried out at 13 weeks after planting when more than $80 \%$ of the pods were dried. Two subsequent pickings were also carried out to ensure that the cowpeas were fully harvested. The dry pods from each of the plots were put in polythene bags, labeled and carried to the laboratory where the dry weight was measured. 20 pods were randomly selected from each bag to assess the pod shrivelling caused by $C$. tomentosicollis. Yields were measured for each of the plots.

All the data generated were subjected to the analysis of variance (ANOVA) to test the significance using F-test. The least significant difference (LSD) was used to separate the means (Gomez and Gomez, 1983).

\section{Results}

Results of the experiment indicated that there was no significant difference in population of $\mathrm{C}$. tomentosicollis $(\mathrm{P}>0.05)$ between the treated plots and the control, as shown in Table 1. At first spraying (9 weeks after planting), the highest population of $C$. tomentosicollis was obtained from the control where a mean of 14.00 was recorded, followed by $2 \%$ concentration of the slurry (8.50), and the $8 \%$ concentration plot recorded the lowest mean population of 2.75 .

At the end, even though there was no significant difference during the weeks of spraying, the treated plots recorded the lowest population compared with the control plots.

Considering the effect of black soap/kerosene mixture on the damage by C. tomentosicollis (pod shrivelling), there was a significant difference $(\mathrm{P}<0.05)$ between the various treated plots and the control as shown in Table 2. The control recorded the highest percentage of damage (88.8\%) at the end of the season, while $8 \%$ concentration of the slurry recorded the lowest (45\%) followed by $6 \%$ concentration of the slurry which recorded $48.8 \%$. 
Aliyu M. et al.

Similarly, considering the dry pods yield after harvest, the highest yield of $1437.5 \mathrm{~kg} / \mathrm{ha}$ was obtained from $8 \%$ concentration of the slurry, followed by $6 \%$ concentration of the slurry which recorded $1325.0 \mathrm{~kg} / \mathrm{ha}$, while the control recorded the lowest yield of $606.3 \mathrm{~kg} / \mathrm{ha}$. (Table 3) There was a significant difference $(\mathrm{P}<0.05)$ between the treatments and the control.

Table 1. Effect of black soap/kerosene mixture on the population of C. tomentosicollis.

\begin{tabular}{lccc}
\hline & \multicolumn{3}{c}{ Weeks After Planting (WAP) } \\
\cline { 2 - 4 } Slurry Concentration & $\mathbf{9}$ & $\mathbf{1 0}$ & $\mathbf{1 1}$ \\
\hline $\mathbf{2 \%}$ & 9.5 & 8.25 & 2.25 \\
$\mathbf{4 \%}$ & 8.25 & 7 & 2.25 \\
$\mathbf{6 \%}$ & 7.5 & 5.25 & 1.75 \\
$\mathbf{8 \%}$ & 6.75 & 5 & 1.5 \\
Control & 14 & 11 & 3.25 \\
Level of significance & N.S & N.S & N.S \\
SE \pm & 6.98 & 6.44 & 1.76 \\
\hline
\end{tabular}

S.E. $=$ Standard error; WAP $=$ Weeks after planting

Table 2. Effects of black soap/kerosene mixture on the damage caused by $C$. tometosicollis.

\begin{tabular}{lc}
\hline Slurry Concentration & Percentage of pods shriveled (\%) \\
\hline $\mathbf{2 \%}$ & 48.8 \\
$\mathbf{4 \%}$ & 66.3 \\
$\mathbf{6 \%}$ & 48.8 \\
$\mathbf{8 \%}$ & 45.0 \\
Control & 88.8 \\
Level of significance & $*$ \\
LSD(0.05) & 19.13 \\
\hline \multicolumn{2}{c}{ LSD = Least significant difference, * }
\end{tabular}

Table 3. Effects of black soap/kerosene mixture on the yield of cowpea.

\begin{tabular}{lc}
\hline Slurry Concentration & Percentage yield (kg/ha) \\
\hline $\mathbf{2 \%}$ & 856.3 \\
$\mathbf{4 \%}$ & 1031.2 \\
$\mathbf{6 \%}$ & 1325.0 \\
$\mathbf{8 \%}$ & 1437.0 \\
$\mathbf{C o n t r o l}$ & 606.3 \\
Level of significance & $* *$ \\
LSD(0.01) & 284.7 \\
\hline LSD = Least significance Difference; $* *=$ & highly significant
\end{tabular}




\section{Discussion}

Using the black soap/kerosene mixture obtained in this study exhibited various levels of reduction of population of the pod sucking bugs compared with the control.

C. tomentosicollis attack the cowpea crop at the podding stage of the plants' development. Many other insects were also found to infest the crop at different stages of development; however the $C$. tometosicollis was the dominant species during the podding stage. The potential loss in yield that it causes could be up to 80\% (IITA, 2004). These insects were found when the pods were matured, with adults and nymphs aggregated in large clumps. They moved all over the plant and were found in the developing cowpea grains sucking the sap from the seeds. The cowpea grains from pods that were attacked by $C$. tometosicollis were shriveled and malformed, and they were much smaller than the healthy grains. The results obtained from this experiment showed that the use of black soap/kerosene mixture can suppress the population of $C$. tometosicollis. The suppression of $C$. tomentosicollis numbers in cowpea pods could be due to suffocation and antifeeding activity of the black soap/kerosene mixture. Since the insects live inside the preferred structures of the cowpea plant outside the reach of most insecticides, it is suspected that the mixture is absorbed by the pods through osmotic pressure, thereby causing the insects to stop feeding on the pods. It is also possible that, as the pods absorbed the spray liquid, the soft body of $C$. tomentosicollis larvae living and feeding on the preferred plant parts could have absorbed the mixture, resulting in death of the insects. This study also elucidates the potential of black soap/kerosene mixture as a biocide for management of C. tomentosicollis on cowpea plants. The number of the bugs was drastically reduced in plots sprayed with the mixture and the mechanisms of action could be contact, since some of the bugs were found on the ground some few minutes after spraying exhibiting symptoms of hyper-excitability, staggered walking using one side of the limbs, abdominal extrusion and death. It can also minimize the pod damage and increase the yield several times more than control. The application of $8 \%$ concentration of the slurry proved to be the best in suppressing the insects' population, minimizing the pods damaged and increasing potential yields. The purpose of any sound pest management by non-chemicals is not only to reduce pest population but to equally reduce loss of crop yield and quality.

$$
\text { Although the economic }
$$
importance of controlling pests is well known in Nigeria, as reported by Kayumba (1976), as of now, there has been no cowpea variety released that is resistant to this pest. Early planting can reduce the population of $C$. tometosicollis as reported by Hammond (1983) who planted in early July in this same location. Success has also been recorded in controlling these pests on cowpeas with synthetic pyrethroids (Dina, 1979), but they often have mammalian toxicity. Neem powder solution has also been reported to control C. tometosicollis (Joseph et al., 1997). Chemical pesticides in practice are the major control measures of C. tometosicollis on cowpea (Singh and Jackai, 1985, Singh et al., 1990 and Adalla 1997). This increased use of chemicals is undesirable for the environment, especially since the cowpea is grown over a wide area, and they have detrimental effects on the environment. Moreover, widespread resistances to chemical pesticides by the insects have been reported from various parts of the world (Royer et al., 1986, Bradsgaard, 1994 and Immaraju et al., 1992). Solutions to these problems have to be found that will concur with our long term interests, for the potential hazards are too great to become purely a function of 
chemical pesticides. Therefore, the results obtained from this study indicated the use of a black soap/kerosene mixture could provide a good alternative to the use of chemical pesticides. Furthermore the black soap/kerosene mixture is easy to prepare and affordable for the small scale rural farmers. The materials did not show any phytotoxicity effect on the treated plants. In Bauchi state where the trial was conducted, all the materials used are readily available for local farmers' use. The biodegradable properties of these materials would also reduce any potential hazard to the environment.

The use of black soap/kerosene could be in combination with other cultural control measures such as early sowing and planting early maturing varieties to give more effective control measures. This may serve as an important component of integrated pest measurement (IPM). The yields obtained from this study also pointed to the fact that a farmer is more assured of better returns by increasing the concentration up to $8 \%$ concentration of the slurry in one hectare, though further researches needs to be carry out to find out the optimum concentration. The poor results in insects' population were due to shortage of rainfall during the peak period of podding (11weeks after planting). The insects obtained also indicated that the black soap/kerosene mixture minimized the pod damage with increase in the concentration of the mixture which reduces the population of $C$. tomentosicollis. The use of application of $8 \%$ concentration of the slurry in water per hectare could therefore be suggested to cowpea producers based on the numbers insects obtained from this study. Further studies are also required to find out the effects of these materials on other insect pests of other cultivated crops, testing their appropriate spraying regimes for effectiveness and also to ascertain the optimum concentration and spraying frequency that will be adequate for effective control of this pest, and thereby ensuring reasonable grain yield on the farms. The technology is cheap, safe, easily adoptable and environmentally friendly.

\section{References}

Bradsgaard, H. F. 1994. Effect of photoperiod on the bionomics of Frankliniella occidentals (Pergande) (Thysonoptera). 177:498-507.

Dal. Bello, C., Padina, S., Lapazlastra, C. and Fabrizio. 2001. Laboratory evaluation of chemical and biological Control of Rice Weevils (Sitophilus oryzae L.) in stored grain. Journal of Stored Products Research. 37:77-84.

Dina, S. O. 1979. Synthetic Pyrethroids for the control of cowpea insect pests. Journal of Agricultural Science, Cambridge. 93:735-742.

Ekesi, S. Egwurube E. A., Akpan, I. and Onu, I. 2001. Laboratory Evaluation of Entomopathogeneric fungi Metrhizium anisopliae for the control of Groundnuts Bruchid, (Cavyedon serrates) on Groundnut. Journal of Stored Products Research. 37:313-321.

Gomez, K. A. and Gomez, A. A. 1983. Statistical procedures for agricultural research. pp. 674 .

Hammond, W. N. O. 1983. The Biology of pod sucking bugs of cowpea (Vigna unguiculata L. walp) with special reference to Clavigralla $s p$ and their host range in Nigeria. MSc. Thesis, University of Ghana. pp.138.

IITA. 2004. Crops and Farming Systems. International Institute of Tropical Agriculture. http://www.iita.org crop/cowpea. pp. 1-3 
Emir. J. Food Agric. 2007. 19 (2): 08-14

http://www.cfa.uaeu.ac.ae/research/ejfa.htm

Immaraju, J. A., T. O. Paine, J. A. Bethke, K. L. Robb. (Thysanoptera: Thripidae) Resistance to insecticides in coastal California greenhouses Journal of Economic Entomology. 85:9-14.

Jackai L. E. N. and C. B. Adalla. 1997. Pest Management Practices in Cowpea: A review in: B. B. Singh, D. R. Mohan Raj. Devon (Eds). pp. 240-258. Advances in Cowpea research.

Joseph, L. J. Maryem, and A. Valencia. 1997. SG 2000, Nigeria Project. Federal Agricultural Coordinating Unit Abuja. pp.126.

Kayumbo, H. Y. (1976). Pest Control in Mixed Cropping Systems in: Intercropping in some arid area. Symposium held at the institute of Agriculture, Forestry and Veterinary Science University of Dares-Salam, Morogoro, Tanzania. pp.39-40.

Nelson, S. S., T. A. Ohlev, and C. A. Mitchel. 1997. Cowpea leaves for consumption: Production, utilization and nutrient composition. In: B. B. Singh, D. R. Mohan Raj, K. E. Dashiell and L. E. N. Jackai (Eds). pp. 326-332. Advances in cowpea research. Devon Sayce Publishing.

Quin, F. M. 1997. Introduction in: Advances in Cowpea Research. Devon Sayce Publishing, pp.4-15.

Royer, T. A., J. V. Edelson and B. Cartwright. 1986. Damage and Control of Thrips. tabaci: Lindeman on Spring Onion. Journal of Rio Coronde Valley Horticultural Society. 39:69-74.
Shri, R. J., M. P. Gupta, and B. D. Partils. 1989. Pest Management in Fodder Cowpea (Vigna unguiculata L. Walp) through mixed and intercropping in India. Tropical Pest Management. 35:45-347.

Singh, S. R. and D. J. Allen. 1980. Pests, Disease, Resistance and Protection in Cowpea. In: R. J. Summafield and A. H. Bunching (Eds). pp. 419443. Advances in Legume Science.

Singh, S. R. and Jackai, L. E. N. 1985. Insect Pests of Cowpea in Africa, their life cycle, ecology, importance and potential, In: S. R. Singh and K. O. Rachie (Eds). pp.217-231. Cowpea Research Production and Utilization.

Singh, S. R. and K. O. Rachie. 1985. Introduction in Cowpea Research, Production and Utilization, In: S. R. Singh and K. O. Rachie (Eds.). pp. 121-128. New York, John Wiley and Sons.

Singh S. R., L. E. N. Jackai, J. H. R. Dos Santos and C. B. Adalla. 1990. Insect Pest of Cowpea. In: Insect Pests of Tropical Food Legumes. (S. R. Singh Ed.) Chichester, John Wiley and Sons. pp. 43-89.

Yewunga, V. A. 1987. Agriculture in Nigeria. An Introduction to Food and Agricultural Organization United Nations, Rome. Pp. 326. 